\title{
ESTUDO DE CASO NA EMPRESA NATURA: PLANEJAMENTO E DIAGNÓSTICO ESTRATÉGICO
}

\section{Raphaelly Antunes Alves ${ }^{1}$ \\ Romário Carlos Martins ${ }^{2}$ \\ Paulo Henrique Paulista ${ }^{3}$}

Resumo: No atual cenário mundial, as empresas se sentem no dever de planejar estratégias para se manterem economicamente, onde uma estratégia bem definida deve considerar o ambiente interno e externo da organização. Modos para checar o planejamento estratégico, como a análise das cinco forças competitivas será implicada neste artigo mostrando como a Natura pratica os principais aspectos para a empresa obter maior competitividade e garantir sua sobrevivência. Termos teóricos como missão, visão, matriz SWOT e valor de uma empresa também serão abordados, medidas para que a empresa trabalhe de acordo com suas políticas pré-definidas.

Palavras-chave: Planejamento; Análise SWOT; Estratégia; Diagnóstico estratégico.

\footnotetext{
${ }^{1}$ Engenharia de Produção/FEPI, Brasil. E-mail: raphaelly.alvez@hotmail.com. ${ }^{2}$ Engenharia de Produção/FEPI, Brasil. E-mail: pnetromario@hotmail.com.

${ }^{3}$ Engenharia de Produção/FEPI, Brasil. E-mail: paulohpaulista@gmail.com.
} 